\title{
VIGVÁRI ANDRÁS: KÖZPÉNZÜGYEINK
}

\author{
(KJK-KERSZÖV, Budapest, 2005', 385 o.)
}

\section{KOVÁCS RÓBERT}

Egyre többet beszélünk a közszektor finanszírozásáról, az államháztartásról, de az érvek legtöbbször megmaradnak a sematikus közhelyek szintjén. Vígvári András banki tapasztalatokkal rendelkezỏ pénzügyi szakember, aki jelenleg az Állami Számvevőszék szakértőjeként egyszerre tekint elméleti és gyakorlati szemlélet-móddal a közösségi pénzügyekre. A szerzö elméleti munkásságának fontos állomása volt a 2004-ben szintén a KJK-Kerszövnél megjelent „Pénzügy(rendszer)tan” címü kötete. A „Közpénzügyeink” kézikönyv és modern szemléletủ tankönyv, amely olvasója számára több rétegben közöl információt. Piktogramokkal orientálja az érdeklődőt, széleskörú magyarázati apparátussal segíti a szövegértést, és emlékeztetö összegzésekkel, kérdésekkel ön-tesztet biztosít a tanulmányaikat végzők számára. A munka didaktikai eszközrendszerében messze túlmutat a hagyományos tankönyveken, magyarázataiban plasztikusságra és kézzelfoghatóságra törekszik. Logikusan és jól követhetô módon felépített, magyarázatokkal, példákkal, ábrákkal és táblázatokkal gazdagon illusztrált anyagról van szó, amelynek kiérleltségét mutatja, hogy a „Közpénzügyek, önkormányzati pénzügyek" címmel már 2002-ben publikált a szerző a kiadónál egy kötetet, amelynek a jelen kötet egyfajta átdolgozásának, továbbgondolásának, legfrissebb pedagógia-oktatói tapasztalatai beépítésének tekinthető. A könyv tehát egyszerre lehet hasznos a kutató számára a munkájában, a diák számára egyetemi és posztgraduális tanulmányai során, illetve a hétköznapokban eligazodni kívánó nem szakemberek számára.

Azt a tényt, hogy a közszektor, a közszektor gazdálkodása a közfigyelem középpontjába került, a Vígvári András által is tárgyalt Wagner-törvény, vagyis a közszektor növekedésének törvénye magyarázza. Közgazdász-pénzügyesként a szerzỏ a közszektor létjogosultságát a piacgazdaságban, a piaci mechanizmusok múkődésének „kudarcaiban” keresi, és találja meg ott, ahol nincsenek árak, nem lehetséges a verseny, illetve nem zárhatók ki a fogyasztók az adott szolgáltatásból, de mindenekelött a közszektor 4 alapfunkciójában: a szabályozásban, a stabilizációban, az allokációban és a redisztribúcióban. E funkciók, de mindenekelött az újabb és újabb területeken megjelenő közösségi szerepvállalás a magyarázata a fejlett világban a GDP felére rúgó közszektornak. A szerző rámutat azokra a mintegy 20 éves erőfeszítésekre, és azok sikerességének korlátaira, amelyek a közszektor burjánzásának megfékezését, valamint alternatív ellátási, szolgáltatási módok kialakítását célozzák meg.

Miközben a kötet erényeit vesszük számba, számomra talán a legfontosabb az a szemlélet, ahogy a szerző a tárgyalt problémát, saját szakterületét megközelíti. Szemben az általánosan jellemzö szakmai ortodoxiákkal, amelyek azt tekintik komoly tudománynak, ami nem felfogható, nem közérthető, és ennek fokozása 
Tér és Társadalom 20. évf. 2006/3. 109-158. p.

érdekében minél szofisztikáltabb szakmai nyelvet alkalmaznak, Vígvári András képes kitekinteni saját szükebb szakmájából, amelyről ő is tudja, hogy sokan a „,száraz” tudományok közé sorolják. Arra tesz tehát kísérletet, hogy úgy adja át szakmai ismereteit, hogy azok a szakmai precizitás követelményeinek sérülése nélkül közérthetővé váljanak. Ennek az erőfeszítésnek kiemelkedő példája a „Prológus", amely egy tetszőleges magyar város problémáin keresztül szemlélteti a kötetben tárgyalt legfontosabb kérdéseket, a közfinanszírozás problematikáját, de erre utal a cím is (közpénzügyeink), amely kicsit kikacsint a dogmatikusan illendö „,közszektor finanszírozás”-fogalom mögül.

A kötet első felében a közszektor közgazdasági problémáit elemzi a szerző, míg a második felét sajátos tematikus problémáknak szentelte. A közszektor hel yét kereső elméleti részek a kormányzat funkcióival, a közszektor mikro-ökonómiai hatásaival, a közpénzügyi rendszerrel és annak gazdasági hatásával, valamint a költségvetés funkcióival foglalkoznak. Ezen elméleti részekhez sorolható a kötet két zárófejezete, amelyek a kontrolling alapjait, illetve a közpénzek ellenőrzését tárgyalják. A zárófejezeteket három tematikus fejezet elözi meg, amelyek a magyar államháztartás rendszeréról, az Európai Unió költségvetési rendszeréről, illetve a területfejlesztés pénzügyi eszközrendszeréröl szólnak.

A prológust követó első fejezet tehát a közszektor helyét keresi a vegyes piacgazdaságban, és bemutatja, hogy a különböző közgazdasági iskolák hogyan közelítik meg a kérdést. Ezt követôen megismerhetjük a közszektor müködésének sajátos problémáit. A fentebb már említett „rivalizálás” és a „szolgáltatásból való kizárás lehetôsége” dimenziónak bevezetésén keresztuil a szerző megkülönbözeti a „,magánjavakat” és a „közjavakat”. A köz- vagy kollektív javak fogalmán keresztül találja meg a közösségi felelősségvállalás elsődleges terepét. Láthatjuk, hogy e fogalmak tartalma változhat térben és időben, megismerhetjük a közszolgáltatások célrendszerét, az ezek körében kialakuló gazdasági viszonyokat, a feladatok közszolgáltatás keretében történő üzemeltetésének korlátjait is. Vígvári András a rendszerszemléletủ közpénzügyek funkcióit a forrásteremtésben, a forrásallokációban, az újraelosztásban, az ösztönzési és irányítási funkcióban, a kockázatok kezelésében, valamint a közpénzek és a közösségi vagyon felhasználásának ellenőrzésében látja. Kiemelt teret szentel a közpénzügyi rendszer pénzügyi instrumentumainak: az adóknak, a díjaknạk, a transzfereknek és a hiteleknek, amelyeket a pénzügyi rendszer más elemeinél részletesebben tárgyal. A közszektor müködésének több általános és ágazati modellváltozatát elemzi, ahol funkciók és elemek világos rendbe állnak össze. Ezt követốen köti össze a szerzô a közszektor funkcióit és a feladatok finanszírozását, a finanszírozás hatásait, mint például a deficitet és az államháztartási hiányt. Végül teret szentel a hatások mérését szolgáló mutatószámoknak, valamint a költségvetés felépítésének és gazdálkodási funkcióinak.

A specializált fejezetek közül az első a magyar államháztartással foglalkozik. Ez a fejezet sorra veszi a magyar államháztartás alrendszereit és bemutatja azok múködését, feladatait. Ugyanakkor figyelmet szentel a rendszer dinamikájának átalakulásának is, így az értékelése egyfajta jövöorientáltságot kap. A második speciális fejezet 
az Európai Unió pénzügyi költségvetési rendszerével foglalkozik. Számtalan önálló munka található, amely e téma kimerítő elemzésére vállalkozik, ugyanakkor Vígvári András mindezt a közszektor általános, kritikai elemzési keretébe helyezi, ahol a sajátos uniós intézményrendszer új értelmet nyer. Világosabbá válnak a funkciói, céljai. A szerző ezt igyekszik megerösíteni a kötetet jellemző rendszerszemléletü tárgyalásmódjával, amelynek segítségével egy-egy intézmény helye, szerepe sokkal világosabban rajzolódik ki. A területfejlesztési fejezetben megjelenik a tér problematikája, a területi intézményrendszer, mint sajátos közgazdasági kérdés. Másrészröl viszont a fejezet szervesen ráépül az elözó részben, az unió vonatkozásában elsajátítottakra.

A kötet fejezeteinek sorrendjét követve elérkeztünk a két zárófejezethez, amelyek a kontrolling és az ellenörzés témakörét tárgyalják. Vagyis visszatérünk a szükebb értelemben vett pénzügyi intézményrendszerhez. Az elỏbbi az irányítási és számviteli kérdéseket tárgyalja, közben azonban kitér olyan általánosabb jelentőségú kérdésekre, mint a teljesítmény- és költségmérés, amelyek jelentősége messze túlmutat a szükebb értelemben vett pénzügyi rendszeren. Ezek ma a közszektor átalakulásának legalapvetöbb kérdései az átlátható feladatszervezés és hatékony feladatellátás kérdései mellett, amelyektöl nem is teljesen elválaszthatóak.

A kötet jelentős didaktikai apparátussal segíti a téma iránt érdeklődőket, illetve a kötetet tanulási céllal forgatókat. Ezt tükrözi a tematikus egységek szerkezete. A fejezetek rövid összegzéssel, tartalom- és ábrajegyzékkel kezdődnek, belső részeikben más hasonló munkáknál több adat- és analitikus táblák, valamint magyarázó ábrák segítik a szöveg megértését, támasztják alá az elmondottakat. Felkiáltójellel jelölt megjegyzések emlékeztetnek sajátos összefüggésekre, egy nyitott könyv hívja fel a figyelmet, hogy háttér-információk következnek, egy „arcél” pedig a kapcsolódó neves személyiségek életrajzának ismertetésére. A kötetben külön jelzik azokat a részeket, amelyek $\mathrm{PhD}$ képzés tárgyát képezik. A megszerzett tudás ellenörzését, elmélyítését szolgálják a fejezetek végén található kulcsfogalmak, ellenőrző kérdések, vitakérdések, internetes feladatok, valamint a felhasznált és ajánlott irodalom. További segítséget nyújt a kötet elején a rövidítések, a kötet végén pedig a fogalmak részletes magyarázata.

Végül hadd hívjam fel az olvasó figyelmét a könyv egyfajta különlegességére. A fejezetek lezárása nem a hagyományos ismétlö-összefoglalás formájában történik. Vígvári András a fejezetek végén „Mi mennyi” címmel mintegy pénzügyi mérleget von, egyenleget készít a fejezetben tárgyalt központi kérdés vonatkozásában, ami például az uniós fejezet esetében az integráció előnyeire és hátrányaira is kiterjed.

Vígvári András munkája tehát szakembereknek, társterületek szakértőinek és diákoknak egyaránt fontos eszköz lehet ismereteik elmélyítésében vagy akár csak egyegy kérdéssel kapcsolatosan felmerült kételyeik tisztázásában. 
Tér és Társadalom 20. évf. 2006/3. 109-158. p. 